\title{
ОГЛЯДИ
}

УДК 612.17+612.273.2+616.005.4

\section{Remote ischemic preconditioning versus intermittent hypoxia training: a comparative analysis for cardioprotection}

\author{
T.V. Serebrovska ${ }^{1}$, V.B. Shatilo ${ }^{2}$ \\ ${ }^{1}$ O.O.Bogomoletz Institute of Physiology,Kyiv,Ukraine, sereb@biph.kiev.ua \\ ${ }^{2}$ D.F. Chebotarev State Institute of Gerontology, Kyiv, Ukraine
}

\begin{abstract}
Ischemic preconditioning (IPC) is an adaptive phenomenon that occurs after one or more short periods of ischemia / reperfusion, and consists in increasing the tolerance of an organ or tissue to the damaging effect of a long period of ischemia / reperfusion. Although IPC was shown to have a protective effect in animal models or during operative interventions, the obvious difficulties involved in subjecting the heart to direct $I P C$ restrict its potential clinical applications. In this perspective, the phenomenon of remote ischemic preconditioning (RIPC: ischemia/reperfusion cycles in the arm or leg) appears extremely encouraging. Intermittent hypoxic training (IHT, periodic exposure of an organism to hypoxic gas mixtures, or stay in the chamber or altitudes) also has powerful adaptogenic effect increasing the resistance to subsequent episodes of severe hypoxia / ischemia. This review discusses main mechanisms and clinical applications of RIPC in cardiology versus IHT technologies. Benefits and disadvantages of both methods are under consideration. Positive and negative effects of hypercapnia during the RIPC technology are also examined. We wish to stimulate a comprehensive understanding of such a complex physiological phenomenon as intermittent hypoxia and ischemic preconditioning in order to prevent or reduce their harmful consequences, while maximize their potential utility as an effective therapeutic tools.

Key words: remote ischemic preconditioning, intermittent hypoxia training, hypoxic-hyperoxic training, cardiovascular diseases, adaptation to hypoxia, hypercapnia
\end{abstract}

\section{INTRODUCTION}

Hypoxia is a fundamental stimulus that evokes both adaptive and maladaptive responses. Prabhakar \& Semenza [1] define hypoxia as a reduction in $\mathrm{O}_{2}$ availability in one state or condition compared with another; as such, it is a highly relative term. Over the past two decades, the term "intermittent hypoxia" (IH) actively entered into scientific practice. IH refers to repeating periods of hypoxia (from seconds to several hours or even days) that are followed by similar periods of normoxia.

A broad interpretation of this term led Greg Semenza to put a question: "What is "intermittent hypoxia"? Does it play pathogenic roles in disease states, such as sleep-disordered breathing, chronic pulmonary disease, cardiovascular disease, and cancer? Or, quite to the contrary, does exposure to intermittent hypoxia induce protective responses?" [2]. It is appropriate to mention here the ancient wisdom well expressed by Paracelsus in the XYI ${ }^{\text {th }}$ century: "Sola dosis facit venenum" (Only the dose makes the poison). So, the mode of hypoxic influence (depth, duration, and intermittence) appeared to be critical for the determination of healing or harmful result.

Great confusion in the concept of intermittent hypoxia makes the fact that different authors identify it with completely different influences. These include such paradigms of hypoxia as preconditioning effects of brief

(C) T.V. Serebrovska and V.B. Shatilo 
episodes of low-frequency $\mathrm{IH}$; exercise training in hypoxic conditions; maladaptation to $\mathrm{IH}$ in patients with obstructive sleep apnoe (OSA) and many others [3]. Moreover, some authors identify the notion "hypoxic preconditioning" with "ischemic preconditioning" (IPC). Hypoxic preconditioning refers to the periodic exposure of organisms, systems, organs, tissues or cells to moderate hypoxia/ischemia that results in increased resistance to a subsequent episode of severe hypoxia/ischemia, thus putting an equal sign between hypoxia and ischemia [4-7].

Some authors use the term "hypoxic preconditioning" to refer to a single exposure of inhalation of hypoxic mixture or stay at barochamber. For example, Portnichenko et al [8] have shown that single exposure of acute hypoxia (inhalation of $10 \% \mathrm{O}_{2}$ during 3 hours) prevents the induction and activation of 5-lipoxygenase during ischemia and reperfusion of rat heart. In addition, in the papers associated with diving, the term "preconditioning" used to describe the procedure of hyperbaric oxygenation before deep sea diving [9]. Terms "pretreatment" and "preconditioning" also found in the literature as synonyms. Some authors identify the term "adaptation to intermittent hypoxia" (daily periodic exposures to hypoxia for two to four weeks) with "hypoxic preconditioning" $[4-5,10]$.

In an attempt to clarify this issue, other authors propose different classifications of IH species. For example, Milano et al [11] describe three different models of hypoxia, each with its own specific effects on myocardial tolerance to ischemia: 1) chronic hypoxia $(\mathrm{CH})$ - high altitude; chronic obstructive pulmonary and congenital heart disease; anemia; blood $\mathrm{O}_{2}$ carrying abnormalities; $\mathrm{CO}$ poisoning; chronically decreased tissue perfusion; 2) chronic hypoxia with aeration (CHA) - repetitive short-term reoxygenation episodes during hypoxia (studies whereby animals are housed in hypoxic or hypobaric chambers that are routinely opened to allow operations such as cleaning and animal feeding); 3) intermittent hypoxia $(I H)$ - obstructive sleep apnea; sickle cell anemia, crises; asthma; live high train low; therapeutic intermittent exposure to normobaric or hypobaric hypoxia. Severe chronic hypoxia invariably leads to depressed myocardial tolerance to ischemia, but moderate chronic hypoxia may be considered as cardioprotective. Chronic hypoxia with aeration is almost always protective. By contrast with the IH pattern associated with obstructive sleep apnea, other forms of IH the authors consider as protective.

Besides, depending of type of hypoxic exposure (high altitudes, barochamber, inhalation of gas mixtures, or breath holding and ischemia), the unfolding events are accompanied by hypocapnia and alkalosis or hypercapnia and acidosis. But the physiological consequences of elevated or reduced $\mathrm{CO}_{2}$ levels under intermittent hypoxic technologies are very poorly elucidated. All these facts suggest that the common terminology on the issue of IPC and adaptation to hypoxia has not yet taken shape.

However, despite all the confusions and disagreements, all the authors believe that both intermittent hypoxic exposures in different modes and different types of ischemic preconditioning can be successfully used for the treatment and prevention of many diseases, particularly cardiovascular disorders. Mechanisms of protective actions of hypoxic and ischemic impacts have been investigated during last decades at different levels - from genomic to systemic.

Methodological approaches to the implementation of the preconditioning are extremely broad. In recent years, researchers are paying great attention to searching for alternative to IPC approaches to increase the tolerance of organs and tissues to ischemia/reperfusion. Among these attempts, remote ischemic preconditioning (RIPC) is known as a more convenient model for clinical usage. RIPC is the application of a transient and brief ischemic stimulus to a distant site from the organ or tissue that is afterward exposed to injury ischemia, and has been found to reduce ischemia-reperfusion injury in various animal models [12]. The standard protocols 
normally used to deliver RIPC involve a number of short cycles (about $5 \mathrm{~min}$ ) of inflation of a blood pressure (BP) cuff on the arm and/or leg to an inflation pressure of $200 \mathrm{mmHg}$ followed by cuff deflation for a short period of time [13].

In present review we will try to compare the effects of RIPC with the effects of intermittent hypoxia training/treatment (namely IHT - periodic inhalation of hypoxic gas mixtures) in terms of the potential use of these two methods in cardiological practice.

\section{ISCHEMIC PRECONDITIONING}

How ischemia may play 'preconditioning', that is "preparatory" action? Preconditioning is assumed as a natural adaptive process whereby a subthreshold stimulus can promote protection against a subsequent lethal stimulus. Preconditioning has been observed in multiple organisms and can occur in different organs and tissues [14, 15]. According to first definition [16], myocardial IPC is a phenomenon when multiple, brief nonlethal ischemic episodes pre-condition the heart and reduce infarct size caused by a subsequent ischemic insult. Authors exposed anesthetized open-chest dogs to four periods of 5 minute coronary artery occlusions followed by a 5 minute period of reperfusion before the onset of a 40 minute sustained occlusion of the coronary artery. The control animals had no such period of IPC and had much larger infarct sizes compared with the dogs that did. Since then, more than 1400 reviews have been published starting with a review of Schott \& Schaper [17] until today. Pre-, post-, and remote conditionings of the myocardium are well described as adaptive responses that provide therapeutic paradigms for cardioprotection [13].

IPC involves several factors that are usually divided into three groups: triggers, mediators, and effectors [18-20]. The signaling pathways are complex and not yet fully understood. According to different sources, signaling pathways of immediate cytoprotection activate the synthesis of vasodilators (NO) and opening of $\mathrm{K}_{\text {ATP }}$ channels in mitochondria for the reduction of oxidative processes. Induction of genes that follows the conduction of cell signaling to the nucleus intensifies these defense mechanisms due to the synthesis of powerful enzymes iNOS and COX-2, activates the mitochondrial biogenesis and regulates their function using $\mathrm{K}_{\mathrm{ATP}}$ - and $\mathrm{K}_{\mathrm{Ca}}$ channels. These mechanisms are target-oriented at the prevention of oxidative stress and apoptosis.

Hypoxia-inducible factor HIF-1 activates multiple protective pathways in response to ischemia. Direct IPC of the heart was shown to be dependent upon functional interaction of HIF- $1 \alpha$ with the circadian rhythm protein PER2 [21]. However, most investigators consider that our understanding of the sequence of steps is still fragmented.

Brief episodes of ischemia result in the release of initiating factors such as adenosine, opiates and bradykinin which are all endogenously released by ischemic cells [22, 23]. They activate G-protein coupled pathways, which carries a protective signal to an end-effector [24]. Bradykinin is involved in the inflammatory response by regulating the expression of adhesion molecules and the infiltration of leucocytes into the tissues. Bradykinin in low doses attenuates IR-induced leucocyte recruitment and microvascular dysfunction through B2 receptor complex-dependent nitric oxide production [25].

Ischemic preconditioning has been described not only for the myocardium [16] but also for the kidney [26], skeletal muscle [27], brain [28], and liver [29].

Although IPC was shown to have a protective effect in animal models, the obvious difficulties involved in subjecting the heart to direct IPC restrict its potential clinical applications. Both ischemic preconditioning and postconditioning require an invasive intervention applied directly to the myocardium in order to achieve cardioprotection and may therefore be impractical or even harmful, particularly in the setting of an acute myocardial infarction (AMI) [19]. In this perspective, the RIPC phenomenon appears extremely encouraging. 


\section{REMOTE ISCHEMIC PRECONDITIONING}

It has been known long ago that brief coronary artery occlusion preconditioned the myocardium not only within but also outside its perfusion territory [30]. Applying this phenomenon to humans was possible after discovering that the RIPC effect is reproducible after inflating-deflating a cuff placed around the limbs. Thus, there is a noninvasive method to trigger ischemia-reperfusion episodes in remote organs and muscles.

Remote forms of ischemic pre- and postconditioning are started to be used in clinical studies, as the remote application reduces the risk of injuring the target tissue for which protection is pursued [31]. Limb transient ischemia is the preferred method of induction of remote conditioning with evidence supporting its safety. Clinically, RIPC stimulus is generally delivered by inflating the blood pressure cuff tied on the upper arm $20 \mathrm{~mm}$ greater than the systolic blood pressure, rendering the forearm ischemic for $5 \mathrm{~min}$, followed $5 \mathrm{~min}$ reperfusion by deflating the cuff. This cycle is repeated for 3-4 consecutive periods to precondition the tissue and improve the survival.

\section{Mechanisms}

The mechanisms underlying RIPC cardioprotection are similar to those described for classical ischemic preconditioning [32]. But the pathways that links remote organs, on which the preconditioning stimulus is applied, to the target organ or tissue remains mostly unclear.

Potential mechanisms of RIPC are good described in recent reviews [20,33]. Authors consider that despite the uncertainty in fundamental RIPC mechanisms, they can be divided into three main components: (1) humoral, (2) neural, and (3) systemic factors of cardioprotection.

For today, actual identity of the humoral mediators remains unknown despite the fact that many applicants have been proposed for this role. More than ten years ago such RIPC mediators as adenosine, bradykinin, and calcitonin gene-related peptide was described that enter the bloodstream and activate their respective receptors in the myocardium [34-37]. Later on, the role of endocannabinoids was described [38].

Numerous studies unveiled an activation of opioid receptors as a regulatory mechanism in tissues that have been exposed to reperfusion ischemia injury, suggesting that endogenous opioids can confer both acute and chronic ischemic protection $[39,40]$. NO, a known major adenosine-induced vasodilator, has also been associated with the protective effects of preconditioning [12, 41]. Apart from locally induced vasodilation, NO may trigger other signal pathways and induce hepatic heme oxygenase-1 (HO-1), a stress inducible protein with anti-inflammatory effects.

Hydrogen sulfide $\left(\mathrm{H}_{2} \mathrm{~S}\right)$, a metabolite generated by cells under ischemia, has similar properties with $\mathrm{NO}$ and thus could be another possible mediator of the RIPC stimulus [42]. Mitochondrial $\mathrm{K}_{\mathrm{ATP}}$ channels are thought to be a plausible target of the RIPC [43, 44]. Other authors suggest other agents such as heat shock protein 70 (HSP 70), IL-6, IL-8, IL-10, nuclear factor kappa B (NFkB) and TNF- $\alpha$ [25, 45-47].

Neuronal factors. Gill and coauthors [33] characterize these factors as substances that act locally at the remote ischemic territory via afferent neural pathways. The same adenosine or bradykinin acts not directly, but through the afferent nerve fibers, which then relay to efferent nerve fibers terminating on the myocardium to confer cardioprotection. Neurogenic role to cardioprotection via capsaicin, PKC-e, and KATP signaling was elucidated by Jones et al [48].

RIPC appears to offer two distinct phases of endothelial IRI protection, both of which are mediated from the autonomic nervous system [12]. The early, short phase is activated immediately after preconditioning and vanishes within $4 \mathrm{~h}$, whereas the second, prolonged phase presents $24 \mathrm{~h}$ after the preconditioning stimulus and lasts for at least $48 \mathrm{~h}[49,50]$.

Under the systemic factors Gill et al [33] implies genes encoding proteins involved in 
cytokine synthesis, leukocyte chemotaxis, adhesion and migration, exocytosis, innate immunity, signaling pathways, and apoptosis. Ten years before that Konstantinov et al. [51] have shown that RIPC suppressed pro-inflammatory gene transcription in human leukocytes, helping to confer the protective role of RIPC against ischemia/reperfusion.

Mitogenactivated protein kinase pathways might also have a significant role in the preconditioning-induced protection from ischemia [5255]. Thielmann et al. [55] conducted a randomized clinical trial in which patients who received a RIPC stimulus consisting of three cycles of short 5-min episodes of ischemia/reperfusion of the arm before coronary artery bypass graft surgery were found to have significantly reduced postoperative serum levels of cardiac troponin I, which is indicative of cardioprotection.

Saxena et al [25] investigated the impact of RIPC on kinin receptor expression in neutrophils in patients undergoing coronary artery bypass grafting (CABG). Authors concluded that RIPC down-regulated the expression of both kinin $B_{1}$ and $B_{2}$ receptors which persisted for at least $24 \mathrm{~h}$. However, whether this consistent down-regulation translates into clinically measurable decrease in post-cardiopulmonary bypass inflammatory response or not is yet to be established.

Kalakech [56] tested whether RIPC-induced cardioprotection requires HIF-1 $\alpha$ upregulation to be effective. In the first study, wild-type mice and mice heterozygous for HIF-1 $\alpha$ (gene encoding the HIF-1 $\alpha$ protein) were subjected to RIPC immediately before myocardial infarction. Authors concluded that HIF-1 $\alpha$ upregulation is unnecessary in acute RIPC. But another research in mice [57] has led to the opposite result: data indicated that HIF-1 is required for RIPC. A1brecht et al. [58] provided investigation on patients undergoing cardiopulmonary bypass and also demonstrated the involvement of HIF-1a in RIPC-induced cardioprotection.

Connexin 43 (Cx43), an integral membrane protein which expression and phosphorylation after RIPC might have a protective role, is also involved in the list of possible molecular mechanisms [33]. These authors also mention extracellular vesicles as membrane-bound structures containing a high concentration of RNAs and proteins, as well as microRNAs such as miR-144 and miR-1. Authors emphasize that further studies are needed to establish the direct cause and effect relationship of the various active molecules involved in the cardioprotective effect of RIPC.

Thus, most experimental studies on RIPC cardioprotection described above are similar to classical myocardial IPC. They involve the activation of adenosine, opiates and bradykinin action which in turn activate G-protein coupled pathways, synthesis of vasodilators (NO and $\mathrm{H}_{2} \mathrm{~S}$ ), opening of sarcolemmal and mitochondrial $\mathrm{K}_{\text {ATP }}$ channels, the mPTP, etc. The participation of free radicals and HIFs as trigger mechanisms to preconditioning, other agents such as HSP 70, interleukins, and TNF- $\alpha$ are also considered. But there is no evidence about pathways that links remote and target organs.

\section{Clinical applications of RIPC in cardiac surgery} In recent years, remote ischemic conditioning has become the most popular form of mechanical cardioprotection, because the procedure is noninvasive, predictable, precise, safe, and notably avoids manipulation of the coronary culprit lesion [59]. According to Bousselmi et al [20], the first clinical trial in humans was negative [60]. Later on Cheung et al. [61] randomized 37 children scheduled for surgical repair of congenital heart defects. Seventeen children were included in the RIPC group and received four five-minute cycles of ischemia/ reperfusion achieved by inflation-deflation of a cuff placed on the lower limb. Twenty children were included in the control group. The postoperative levels of troponin I and the postoperative inotropic requirement were significantly higher in the control group. It was the first study to demonstrate the cardioprotective effect of RIPC in humans. 
Meanwhile, regarding neonates undergoing cardiopulmonary bypass surgery some authors consider that RIPC does not provide myocardial, renal, or neuronal protection [62].

Takagi \& Umemoto [63] conducted a meta-analysis, drawn from nine randomized controlled trials including 482 patients. The conclusions were that RIPC reduces postoperative myocardial injury, but is not associated with either a reduction in early postoperative mortality or with a reduction in the incidence of postoperative myocardial infarction. In another investigation [19] RIPC was performed after the induction of anesthesia but prior to surgery and occurred within 1 hour. Those patients randomized to receive RIPC had a standard blood pressure cuff placed on the upper arm, inflated to $200 \mathrm{mmHg}$ for $5 \mathrm{~min}$ and then deflated for 5 min, a cycle which will be performed four times in total. For patients with systolic blood pressures above $185 \mathrm{mmHg}$, the cuff was inflated to at least $15 \mathrm{mmHg}$ above the patient's systolic blood pressure. The sham RIPC protocol was also carried out in a control group. Authors stated that RIPC can improve clinical outcomes in higher-risk patients undergoing $\mathrm{CABG}$ and valve surgery.

Hausenloy et al [19] also provided the ERICCA trial - multicentre randomized doubleblinded controlled clinical trial- which recruited 1,610 high-risk patients undergoing $\mathrm{CABG}$ and valve surgery using blood cardioplegia via 27 tertiary centres over 2 years. The primary combined endpoint was cardiovascular death, non-fatal myocardial infarction, coronary revascularization and stroke at 1 year. Secondary endpoints included peri-operative myocardial and acute kidney injury, intensive care unit and hospital stay, inotrope score, left ventricular ejection fraction, changes of quality of life and exercise tolerance. Patients were randomized to receive after induction of anesthesia either RIPC (4 cycles of $5 \mathrm{~min}$ inflation to $200 \mathrm{mmHg}$ and 5 min deflation of a blood pressure cuff placed on the upper arm) or sham RIPC (4 cycles of simulated inflations and deflations of the blood pressure cuff). The authors underline that the findings from the ERICCA trial have the potential to demonstrate that RIPC can improve clinical outcomes in higher-risk patients undergoing $\mathrm{CABG} \pm$ valve surgery. But the concrete results of this trial were not published yet.

Vasdekis [12] reviewed a total of 24 randomized clinical trials evaluating the safety and efficacy of RIPC in different atherosclerotic diseases including abdominal aortic aneurysm, open heart surgery, percutaneous coronary intervention, and intracranial or extracranial atherosclerosis. The findings indicate that an optimal protocol for the induction of RIPC has not been established.

Recent studies of Manchurov and coauthors [64] from Russia demonstrated that RIPC prior to primary percutaneous coronary intervention (PCI) significantly improves endothelial function in patients with acute myocardial infarction and this effect remains constant at least for a week. Forty eight patients with AMI were enrolled. RIPC (intermittent arm ischemia-reperfusion through four cycles of 5-min inflation and 5-min deflation of a blood-pressure cuff to $200 \mathrm{~mm} \mathrm{Hg}$ ) was performed prior to primary PCI. Authors suppose that the improvement of endothelial function may be one of the possible explanations of the effect of RIPC.

In another investigation [65], 60 patients undergoing $\mathrm{CABG}$ surgery were randomized to RIPC $(n=30)$ or control $(n=30)$. RIPC was performed preoperatively by inflating a blood pressure cuff on the upper arm to $200 \mathrm{~mm} \mathrm{Hg}$ for $3 \times 5$ minutes, with 5 minutes reperfusion intervals. Maximal mitochondrial respiration was preserved throughout surgery after RIPC but significantly reduced after aortic crossclamping in control. Incidence of postoperative atrial fibrillation was lower after RIPC versus control. Myocardial expression of microRNAs miR-133a and miR-133b (important regulators of mitochondrial function) increased after aortic cross-clamping in both RIPC and control, whereas miR-1 was upregulated in control only. MiR-338-3p expression was higher 
in RIPC versus control after aortic crossclamping. The authors conclude that RIPC preserves mitochondrial respiration and prevents upregulation of miR-1 in the right atrium during coronary artery bypass graft.

Pavione et al [66] evaluated in randomized controlled trial whether RIPC performed the day before surgery for congenital heart disease with cardiopulmonary bypass attenuates the postoperative inflammatory response and myocardial dysfunction. Authors concluded that late RIPC did not provide clinically relevant cardioprotection. As Yang et al [4] suggest, repetitive hypoxic preconditioning may provide long-lasting protection than single preconditioning against ischemia/reperfusion injury.

Some authors suggested the prospective possibility of using RIPC for the treatment of other diseases, such as type-2 diabetes [67], chronic kidney disease [68] or prevention of transfusionrelated acute lung injury [69]. But the evidence is virtually non-existent in these studies.

There are some attempts to use RIPC in sport practice. For example, Jean-St-Michel et al [70] indicate that RIPC improves maximal performance in highly trained swimmers. This simple technique may be applicable to other sports and, more importantly, to other clinical syndromes in which exercise tolerance is limited by tissue hypoxemia or ischemia. Another authors have also been looked at RIPC as a means of improving performance in highly trained athletes [7173]. Barbosa [74] testify that RIPC applied to the lower limbs delayed the development of fatigue during handgrip exercise, prolonged time to task failure, but was not accompanied by changes in forearm hemodynamics and deoxygenation.

In children, RIPC has also been applied in the lower limb by using a cuff inflation pressure that was $15 \mathrm{~mm}$ of $\mathrm{Hg}$ above the resting systolic pressure [75].

Recent study [76] demonstrates that RIPC (four cycles of lower limb ischemia (5 min) and 5 min of reperfusion) transiently reduces symptoms of acute mountain sickness. However,
Lalonde [77] investigating the effect of the same RIPC regimen on anaerobic performance in healthy participants, concluded that remote ischemic preconditioning does not offer any significant benefits for anaerobic performance. Accoding to Twine et al [78], the largest powered randomised trial in cardiac surgery showed no benefit to RIPC, meta-analyses are generally underpowered. The technique is physiologically sound but remains lacking in clear clinical benefit. Vasdekis et al [12] also conclude that most of the trials focused on postoperative cardiac or renal function after RIPC with conflicting results. However, no severe local adverse events were observed in any patient undergoing limb or arm preconditioning.

So, for today RIPC is used mainly for short-term cardioprotection in cardiac surgery to reduce postoperative myocardial injury after CABG and valve surgery, percutaneous coronary intervention, abdominal aortic aneurysm as well as in children scheduled for surgical repair of congenital heart defects. Several attempts have been made to show the potential effectiveness in sports as well as for the treatment of other diseases such as type- 2 diabetes, chronic kidney disease, acute mountain sickness.

\section{IY. Intermittent hypoxia treatment in cardiology}

Intermittent hypoxia training (IHT, periodic exposure of an organism to hypoxic gas mixtures, or recurrent stay in a barochamber) has powerful adaptogenic effect. This drug-free method, which is almost without contraindications, has been routinely used by about 2 million patients in the last 30 years and revealed good and satisfactory results in $75-95 \%$ of cases $[79,80]$. The number of publications indexed in PUBMED under the key-word "Intermittent Hypoxia" increased from 15 in 1983 to 335 in 2014 of total 2900. Several monographs have been published [ 81 , 82]. Beneficial results of IHT application were obtained for the treatment and prevention of bronchial asthma and chronic obstructive pulmonary disease, cardiological disorders, type 
II diabetes as well as for preparation of patients to surgery. In many other areas of medicine, such as hematology, neurology, gastrointestinal diseases, professional diseases, post radiation disorders of immune system, male reproductive system this method is also successfully used.

Basic investigations led to the proliferation of various methods of IHT exposure and the development of different medical equipment hypoxicators - for its implementation in sport practice and military operations and also for clinical application, including treatment of cardio-vascular disorders.

Many types of protocol with different numbers of hypoxia episodes, severity, and total exposure duration have been used by investigators and these combinations may have resulted in various physiological responses. In practice, normobaric hypoxic regimens vary broadly from 3-12 short hypoxic sessions (2-10 min) with 2-20 min normoxic breaks during 7-30 days to hypoxic influences lasting from $1-12$ hours during 2-90 days [83]. As Navarrete-Opazo et al [84] describe, modest hypoxia (9-16\% inspired $\mathrm{O}_{2}$ ) and low cycle numbers (3-15 episodes per day) most often lead to beneficial effects without pathology, whereas severe hypoxia (2-8\% inspired $\mathrm{O}_{2}$ ) and more episodes per day (482,400 episodes/day) elicit progressively greater pathology. Serebrovskaya et al [83] investigating 5 modes of IHT on gastrocnemius muscle PO2, heart and liver mitochondrial respiration in rats, concluded that the most effective IHT regimen is $5 \mathrm{~min} 12 \% \mathrm{O}_{2}$ with 5 min breaks, five cycles per day during two or three weeks depending on the task of IHT. Accumulating evidence suggests that "low dose" IHT (modest hypoxia, few episodes) may be a simple, safe, and effective treatment with considerable therapeutic potential for multiple clinical disorders.

Intermittent hypobaric hypoxia is also used for treatment of patients with cardiovascular disorders [85-88]. But the use of barochambers are not entirely without risk. Besides, it is very expensive procedure. The disadvantages of hypobaric chambers have prompted increased study of normobaric hypoxia training, and in recent years normobaric breathing of hypoxic gas mixtures has become a practical means of producing $\mathrm{IH}$.

In this review we will elucidate traditional IHT protocols elaborated mostly by scientists from Eastern Europe comprise alternating brief periods (minutes) of breathing with hypoxic gas mixtures followed by a subsequent oxygenation periods (breathing with ambient air or hyperoxic gas mixtures).

\section{Mechanisms}

Numerous modern studies collectively show that IHT stimulates regenerative processes in an organism via several mechanisms:

(1) elicits upregulation of cytoglobins (myoglobin and neuroglobin), which constitute intracellular $\mathrm{O}_{2}$ buffer and provide protection against ROS and RNS [89, 90];

(2) stimulates insulin-independent glucose transport and accumulation of glycogen in the oxygen-sensitive cells (cardiomyocytes and neurons), thus increasing instantly available intracellular energy reserves [91, 92];

(3) incites activator protein-1 and HIFs, the master proteins responsible for numerous adaptational pathways [93, 94];

(4) stimulates erythropoietin (EPO) production having multiple protective and neuroregenerative effects $[95,96]$;

(5) stimulates HSP70, one of the key members in the chaperons family providing protection against injury and facilitating successful recovery after damage [97, 98];

(6) incites growth hormone and insulin-like growth factor-1 (IGF-1) release [99, 100];

(7) enhances antioxidant defense system and increases the resistance of $\mathrm{Na}^{+}-\mathrm{K}^{+}$ATPase to oxidative stress [101, 102];

(8) stimulates endothelial NO production provoking vasodilation, opening of reserve capillaries and preventing $\mathrm{Ca}^{2+}$ overload, which has multiple protective and adaptogenic effects [103];

(9) modulates humoral and cellular immunity [104]; 
(10) stimulates brain-derived growth factor (BDGF) and glial cell-derived growth factor (GDNF) that provide neuronal protection and stimulate neuroregeneration [105];

(11) supports mitochondrial biogenesis and induces selection of non-mutated mtDNA [97];

(12) induces changes within mitochondria increasing the $\mathrm{O}_{2}$ utilization efficiency of ATP production [106];

(13) stimulates activity of natural mesenchimal and hematopoietic stem-cells responsible for repair [104, 107].

When exposed to IHT, the increase in the total number of mitochondria, the reduction of the number of structurally modified organelles, the appearance of energetically active mitochondria is observed [108]. Several protocols of therapeutic, non-damaging intermittent hypoxia, particularly IHT and intermittent hypoxic-hyperoxic training (IHHT) have been demonstrated to significantly increase proliferation, circulation and homing of bone-marrow derived mesenchimal (stromal) stem cells [109, 110].

\section{Use of IHT in cardiac clinic}

Links to reviews devoted to IHT usage for the treatment of cardiovascular diseases, such as systemic hypertension, atherosclerosis, coronary heart disease, metabolic disturbances are available in many papers and monographs $[81,82,85,86,111,112]$. Valuable studies have been conducted to prove beneficial effects of IHT for preoperative preparation of coronary artery bypasses grafting [113], patients with oncological problems [114] as well as pregnant women to planned abdominal delivery [115].

Special attention deserves the assessment of safety and efficacy of IHT implementation in elderly patients with stable angina, chronic coronary artery disease and hypertension. Besides, it was proved that IHT decreases functional age of cardiovascular system in elderly people with accelerated aging. The principles of individual dosing of hypoxic load for elderly patients were developed [116-118].

Collectively, effects of IHT on human cardiovascular system are described as the following: 1) improvement of metabolic processes in the myocardium; 2) enhancement of the myocardial ischemia/reperfusion sustainability (anti-ischemic effect); 3) reduction of free radical damage; 4) improvement of endothelial function and microcirculation; 5) enhancement of inotropic cardiac function; 6) normalization of blood pressure; 7) reduced activity of the sympathetic nervous system; 8) reduced blood viscosity and platelet aggregation.

A variety of technical implementations for IHT has been tested and used in recent decades, including hypobaric chambers, normobaric reduced oxygen rooms and mask-system hypoxicators, which produce hypoxic air in various ways. On the basis of hypoxicators classification, the overview of their design, medical and technical requirements is presented, and the perspectives of their development and industry trends are described as well as advantages and disadvantages of their operation [119].

In most cases gas mixture is formed from atmospheric air using deoxygenating method. Deoxygenation can be carried out by one of the following approaches: (1) gas separation on membranes or fibres [120]; 2) separation of oxygen and nitrogen by solid electrolytes [121]; 3) temporary binding of nitrogen by zeolites with further emission of nitrogen into the mixture [121]; and 4) breathing in semiclosed flow circuit (rebreathing) [119]. Most of the currently manufactured hypoxicators use the methods of gas separation or rebreathing.

In practice, hypoxic regimens that are used for the study of hypoxic adaptations vary broadly from 3-12 short hypoxic sessions (2-10 min) with 2-20 min normoxic breaks during 7-30 days to hypoxic influences lasting from $1-12$ hours during 2-90 days [ 83].

The advantages of intermittent hypoxichyperoxic training (IHHT)

Recently, a new mode of adaptive training was explored, which combines periods of hypoxia and hyperoxia [122-125]. A novel principle of short-term periodic adaptive training 
by varying the oxygen level from hypo- to hyperoxia is substantiated both theoretically and experimentally. Studies supports the viewpoint that moderate periodic generation of free radical signal during hypoxic/hyperoxic bouts causes better induction of antioxidant enzyme protein synthesis then hypoxic/normoxic exposures, that may be an important trigger for specific adaptations.

This technology utilizes portable equipment, similar to the widely used oxygen concentrators, but specially designed for delivery of precisely controllable, intermittent flow of hyperoxic and hypoxic breathing mixture to the patient via facemask [126, 127]. Using this platform for clinical research opens new exciting perspectives in fighting the multitude of cardiovascular, degenerative and age-related diseases [80].

\section{Y. RIPC versus IHT: benefits and disadvantages}

So, both RIPC and IHT technologies at defined doses provide positive effects on the cardiovascular system. These effects have mostly similar mechanisms of protection and share the same signaling pathways. At the same time, they differ in many ways.

RIPC are mainly used for patients undergoing heart surgery whereas IHT is mostly used in therapeutic clinics. RIPC technologies designed generally for one-day course (about 3-4 times for 5 minutes in 5-minute intervals). IHT involves training for $2-3$ weeks. There is no reliable evidence about the duration of positive effects of RIPC technology, while researchers involved in IHT suggest 3 to 6 month period of improvements.

Besides the great differences in timeframe of the two methods, one very important parameter is evident: the presence or absence of hypercapnia.

Indeed, the physiological and molecular consequences of elevated $\mathrm{CO}_{2}$ levels under RIPC technology are very poorly elucidated. Meanwhile, carbon dioxide is an important gaseous molecule that maintains homeostasis and is an important cellular signaling molecule in an organism. $\mathrm{CO}_{2}$ accumulates in the tissues during each episode of cuff inflating, which causes acidemia. On the contrary, during IHT, systemic hypoxia activates ventilation, resulting in hypocapnea and alkalemia.

Almost twenty years ago it was shown that the return from acidotic to normal $\mathrm{pH}$ after reperfusion caused myocytes to lose viability [128]. Recent analysis of physiological changes in the limb during ischemia demonstrated a reduction in $\mathrm{sO}_{2}(\%), \mathrm{pO}_{2}$ levels and $\mathrm{pH}$ as well as an increase in the levels of $\mathrm{CO}_{2}$ and lactate, but without any change in the base excess or $\mathrm{HCO}_{3}^{-}$levels at all cuff inflation pressures in the upper limb [129].

In the literature there are few papers concerning the changes in gas exchange during remote preconditioning, although the role of $\mathrm{CO}_{2}$ and $\mathrm{pH}$ is not discussed. For example, Xia et al [130] in experiments on sheep showed that three episodes of five-minute occlusion and five-minute reperfusion of the iliac artery increased pulmonary vascular resistance and pulmonary arterial pressure and decreased $\mathrm{PaO} 2 / \mathrm{FiO}_{2}$ ratio. Authors concluded that RIPC by transient occlusion of the iliac artery improves lung gas exchange. These data were later confirmed by studies of patients undergoing heart surgery [131]. The authors compared protective effect of remote ischemic preconditioning (RIPCpre) and postconditioning (RIPCpost) (three 10-min cycles of right-side lower-limb ischemia of $250 \mathrm{~mm} \mathrm{Hg}$ ) in patients undergoing complex valvular heart surgery. In both groups, the ratio between $\mathrm{PaO}_{2}$ and $\mathrm{FiO}_{2}$ at $24 \mathrm{~h}$ postoperation was significantly decreased compared with each corresponding baseline value. Unfortunately, $\mathrm{pCO}_{2}$ and other parameters of acid-base balance have not been investigated.

In the whole body the higher $\mathrm{CO}_{2}$ level causes dyspnoea, headache, restlessness, faintness, dulling of consciousness, greatly elevated alveolar ventilation, muscular rigidity and tremors [132]. Systemic intermittent hypercapnia causes long-term ventilatory potentiation [133]. 
$\mathrm{PaCO}_{2}$ alterations may affect vascular dynamics via activation or inactivation of vasoactive factors such as nitric oxide, angiotensin II, endothelin and bradykinin [134]. Hypercapnia is inversely correlated with renal blood flow and causes renal constriction. In kidney cells it rapidly stimulates renal $\mathrm{H}^{+}$secretion [135]. In neuronal cells $\mathrm{HCO}_{3}{ }^{-}$causes direct activation of a soluble adenylyl cyclase (sAC) protein which is targeted to intracellular compartments regulating cell metabolism [136]. Elevated $\mathrm{CO}_{2}$ levels lead to the increase in cyclic AMP (cAMP) level which, in turn, activates PKA, that leads to opening of L-type $\mathrm{Ca}^{2+}$ channels and influx of $\mathrm{Ca}^{2+}$ into cells. Several reports confirmed a cell-damaging effect of severe acidosis [137, 138]. There are other pathophysiological consequences of elevated $\mathrm{CO}_{2}$ which could take place during cuff inflating.

On the other hand, the hypercapnic acidosis may, paradoxically, be helpful in patients with organ failure due to ischemia/reperfusionrelated cellular injury. The mechanisms of such effects could be partly related to the suppression of formation of proinflammatory cytokines and reactive oxygen species in neutrophils, and with the increases in arterial blood oxygenation through improved ventilation-perfusion matching at the lungs [133].

Moreover, some authors consider hypercapnia as a therapeutic remedy. Experiments on invertebrates have shown that moderate acidosis could result in adaptive responses for cell survival and increase tolerance to harmful stress. Acidic treatment significantly increased the gene expression of hypoxia inducible factor (HIF) [139]. According to Dunlop [140], inhalation of $\mathrm{CO}_{2}$ ("therapeutic hypercapnia") may limit oxidative stress and upregulate cytokine expression in the lung and other organs, prevent the adverse effects of sustained exposure to inhaled nitric oxide on right ventricular (RV) systolic function by limiting IL-1-mediated NOS-2 upregulation and consequent nitration. Authors consider that intermittent acidic preconditioning is more effective in preventing oxygen-deprivation injury, compared with prolonged act. The exogenous inhalation of $\mathrm{CO}_{2}$ has been also shown to have beneficial effects on the pulmonary circulation and cardiac function [141-143]. It was even demonstrated that preconditioning with hypercapnic acidosis protects against ischemiainduced cardiomyocytes injury [144, 145].

By analogy with the RIPS, studies of the IHT effects also paid little attention to the role of $\mathrm{CO}_{2}$, although vasoconstrictive action of hypocapnia secondary to hypoxic hyperventilation takes place. Zhang et al [146] investigating experimental hypocapnia and hypercapnia following 14-day IHT $\left(10 \% \mathrm{O}_{2}\right)$ concluded that repetitive normobaric IH exposures significantly diminish variations of cerebral perfusion in response to both hypercapnia and hypocapnia without compromising cerebral tissue oxygenation. Similar results were obtained by Fan $\&$ Kayser [147]. Snow et al. [148] in experiments on rats have shown that hypocapnic but not eucapnic IH increases hematocrit and causes a more profound increase in right ventricular mass than does eucapnic IH.

In general, the meager data on the role of hypocapnia in adaptive processes at IHT do not allow for any practical advice on manipulation with $\mathrm{CO}_{2}$ during IHT and to compare RIPC and IHT in terms of benefit or detrimental role of $\mathrm{CO}_{2}$ in clinical practice. Some authors consider that hypercapnia treatment might be a novel strategy to prevent brain injury in surgically induced circulation arrest. Meanwhile, intracellular acidosis due to hypercapnia raises concerns about potential harmful effects of intermittent hypercapnia. To the regret, this question has not been investigated according to dose-response curves both in RIPC and IHT technologies.

Another approach to compare the two methods is their simplicity, convenience and cost in use. The biggest advantage of RIPC is the simplicity of application and low cost. The disadvantages concern both the methodology for conducting and the severity of the impact. Clamping arm cuff for 5 minutes with the pressure about $200 \mathrm{~mm} \mathrm{Hg}$ causes severe patient 
discomfort, numbness of a limb and other extremely unpleasant sensations. There is limited data on how well the various RIPC protocols may be tolerated by nonanesthetized individuals. Sharma et al [129] investigated the perception of pain associated with RIPC using different cuff inflation pressures. In both the upper and lower limbs, there was a significant increase in the pain score from baseline with all three cuff inflation pressures used for RIPC (140, 160 and $180 \mathrm{~mm}$ $\mathrm{Hg}$ ). RIPC was better tolerated in the upper limb compared with the lower limb at higher cuff inflation pressures. In this regard, IHT is associated with a more comfortable breathing through a mask, although provision of such procedures is more expensive.

Further, potential effects of age, race, drugs, and comorbidity on RIPC response have not been adequately investigated as well as optimal protocols have not been established. There is conflicting evidence regarding the effectiveness of RIPC in patients undergoing different interventions. According to different authors, meta-analyses are generally underpowered; the RIPC technique is physiologically sound but remains lacking in clear clinical benefit.

IHT has a much larger history of development than RIPC, and accumulates much more information about its use in wide areas of medicine other than cardiology. Most achievements in IHT practical implementation are based on a thorough study of the mechanisms of both positive and negative IHT actions. Various types of equipment that allows dosing the degree of hypoxic stress depending on the purpose of training/treatment have been developed and introduced into clinical and sports practice. This equipment is comfortable to use, most devices are equipped with a feedback system to prevent the negative effects of hypoxic overdose. The benefit effects of IHT course last three to six months. There is evidence that some types of diseases can be completely cured with IHT.

The main negative aspect of IHT concerns first of all the lack of accurate development of methods for individual selection of hypoxic regimen for different patients with different groups of diseases. The proper choice of the hypoxic dosage must be titrated for each patient to avoid negative effects of hypoxia and to augment the favorable ones. Extensive multicentre trials for each type of disease have not conducted yet. Optimal protocols for the procedure need to be further determined. The equipment is mainly expensive and requires skilled personnel for its service. Cheap devices such as rebreathers are still not included in the common practice.

We wish to stimulate a comprehensive understanding of such a complex physiological phenomenon as intermittent hypoxia and ischemic preconditioning, in order to prevent or reduce their harmful consequences, while maximize their potential utility as an effective therapeutic tools.

Acknowledgments This study was supported in part by CellGym (Berlin, Germany).

\section{Т.В. Серебровская ${ }^{1}$, В.Б. Шатило ${ }^{2}$ \\ ДИСТАНЦИОННОЕ ИШЕМИЧЕСКОЕ ПРЕКОНДИЦИОНИРОВАНИЕ И ИНТЕРВАЛЬНАЯ ГИПОКСИЯ В КАРДИОПРОТЕКЦИИ: СРАВНИТЕЛЬНЫЙ АНАЛИЗ}

Под ишемическим прекондиционированием понимают адаптивный феномен, возникающий после одного или нескольких коротких промежутков ишемии/ реперфузии и заключающийся в повышении устойчивости органа или ткани к повреждающему действию длительного периода ишемии/реперфузии. Хотя на животных моделях и в ходе хирургических операций доказано, что ишемическое прекондиционирование производит защитный эффект на сердечную мышцу, клиническое применение этого метода чрезвычайно затруднительно. С этой точки зрения, метод дистанционного ишемического прекондиционирования (ДИП - периодическое пережатие манжетой предплечья или ноги) представляется крайне обнадеживающим. Интервальные гипоксические тренировки (ИГТ - периодическое воздействие на целый организм, орган или ткань гипоксическими газовыми смесями, либо пребывание в барокамере или высокогорье) также обладают мощным адаптогенным эффектом, повышающим устойчивость к последующим эпизодам тяжелой гипоксии / ишемии. В обзоре обсуждаются основные механизмы и 
клиническое применение метода ДИП в кардиологии по сравнению с технологиями ИГТ. Рассматриваются преимущества и недостатки обоих методов, а также положительные и отрицательные эффекты гиперкапнии во время технологии ДИП. Мы хотим стимулировать всестороннее исследование такого сложного физиологического явления, как прерывистая гипоксия и ишемия для предотвращения или уменьшения их отрицательных последствий и максимизации их потенциальной полезности в качестве эффективных терапевтических средств.

${ }^{1}$ Институт физиологии им. А.А.Богомольцุа НАН Украиньл, Киев;

2 Государственное учреждение "Институт геронтологии им. Д.Ф. Чеботарева НАМН Украины”, Киев, Украина

\section{Т.В. Серебровська ${ }^{1}$, В.Б. Шатило ${ }^{2}$ ДИСТАНЦІЙНЕ ІШЕМІЧНЕ ПРЕКОНДИЦІОНУВАННЯ І ИНТЕРВАЛЬНАЯ ГІПОКСІЯ В КАРДІОПРОТЕКЦЇ̈: ПОРІВНЯЛЬНИЙ АНАЛІЗ}

Під ішемічним прекондиціонуванням розуміють адаптивний феномен, що виникає після одного або декількох коротких проміжків ішемії / реперфузії і полягає в підвищенні стійкості органа або тканини до шкідливої дії тривалого їх періоду. Хоча на тваринних моделях і під час хірургічних операцій доведено, що ішемічне прекондиціонування спричиняє захисний ефект на серцевий м'яз, клінічне застосування цього методу надзвичайно складне. 3 цієї точки зору, метод дистанційного ішемічного прекондиціонування (ДІП - періодичне стискання манжетою передпліччя або ноги) є вкрай обнадійливим. Інтервальні гіпоксичні тренування (ІГТ періодичний вплив на цілий організм, орган або тканину гіпоксичними газовими сумішами, або перебування в барокамері чи високогір'ї) також мають потужний адаптогенний ефект, підвищуючи стійкість до подальших епізодів важкої гіпоксії / ішемії. В огляді обговорюються основні механізми та клінічне застосування методу ДІП в кардіології в порівнянні $з$ технологіями ІГТ. Розглядаються переваги та недоліки обох методів, а також позитивні і негативні ефекти гіперкапнії під час ДІП. Ми хочемо стимулювати всебічне дослідження такого складного фізіологічного явища, як інтервальна гіпоксія та ішемія для запобігання або зменшення їх негативних наслідків і максимізації потенційної корисності як ефективних терапевтичних засобів.

\footnotetext{
${ }^{1}$ Інститут фізіології ім. О.О.Богомольияя НАН України, sereb@biph.kiev.ua;
}

2 Державна установа “Інститут геронтології ім. Д.Ф. Чеботарьова НАМН Украӥни”, Київ.

\section{REFERENCES}

1. Prabhakar N.R., Semenza G.L. (2012). Adaptive and maladaptive cardiorespiratory responses to continuous and intermittent hypoxia mediated by hypoxia-inducible factors 1 and 2. Physiol. Rev. 92: 967-1003.

2. Semenza GL (2012) Foreword. In: Xi L, Serebrovskaya TV (eds). Intermittent Hypoxia and Human Diseases / Springer, UK, 2012, p. v.

3. Almendros I, Wang Y, Gozal D. The polymorphic and contradictory aspects of intermittent hypoxia. Am J Physiol Lung Cell Mol Physiol. 2014 Jul 15;307(2):L129-40.

4. Yang C.C., Lin L.C., Wu M.S., Chien C.T., Lai M.K. Repetitive hypoxic preconditioning attenuates renal ischemia/ reperfusion induced oxidative injury via upregulating HIF-1 -dependent bcl-2 signaling. Transplantation. 2009; 88: 11: 1251-1260.

5. Chen W.J., Chen H.W., Yu S.L. et al. Gene expression profiles in hypoxic preconditioning using cDNA microarray analysis: altered expression of an angiogenic factor, carcinoembryonic antigen-related cell adhesion molecule 1. Shock. 2005; 24: 2: 124-131.

6. Semenov D.G., Samoilov M.O., Lazarewicz J.W. Preconditioning reduces hypoxia-evoked alterations in glutamatergic $\mathrm{Ca} 2+$ signaling in rat cortex. Acta Neurobiol. Exp. 2008; 68: 2: 169-179.

7. Maslov LN, Lishmanov IuB, Emel'ianova TV, Prut DA, Kolar F, Portnichenko AG, Podoksenov IuK, Khaliulin IG, Wang H, Pei JM. Hypoxic preconditioning as novel approach to prophylaxis of ischemic and reperfusion damage of brain and heart]. Angiol Sosud Khir. 2011;17(3):27-36.

8. Portnichenko AG, Vasilenko MI, Moübenko AA. [Hypoxic preconditioning prevents the induction and activation of 5-lipoxygenase during ischemia and reperfusion of rat heart]. Fiziol Zh. 2012;58(4):21-9.

9. Camporesi EM, Bosco G. Hyperbaric oxygen pretreatment and preconditioning. Undersea Hyperb Med. 2014 May-Jun;41(3):259-63

10. Rybnikova E., Gluschenko T., Tulkova E. et al. Preconditioning induces prolonged expression of transcription factors $\mathrm{pCREB}$ and NF- $\mathrm{KB}$ in the neocortex of rats before and following severe hypobaric hypoxia. J. Neurochem. 2008; 106: 3: 1450-1458.

11. Milano G, Corno AF, Samaja M, Morel S, Vassalli G, von Segesser LK. Daily reoxygenation decreases myocardial injury and improves post-ischaemic recovery after chronic hypoxia. Eur J Cardiothorac Surg. 2010 Apr;37(4):942-9.

12. Vasdekis SN, Athanasiadis D, Lazaris A, Martikos G, Katsanos AH, Tsivgoulis G, Machairas A, Liakakos $\mathrm{T}$. The role of remote ischemic preconditioning in the treatment of atherosclerotic diseases. Brain Behav. 2013 Nov;3(6):606-16.

13. Ferdinandy P, Hausenloy DJ, Heusch G, Baxter GF, Schulz R. Interaction of risk factors, comorbidities, and comedications with ischemia/reperfusion injury and cardiopro- 
tection by preconditioning, postconditioning, and remote conditioning. Pharmacol Rev. 2014 Oct;66(4):1142-74.

14. Stetler RA, Leak RK, Gan Y, Li P, Zhang F, Hu X, Jing Z, Chen J, Zigmond MJ, Gao Y. Preconditioningprovides neuroprotection in models of CNS disease: paradigms and clinical significance. Prog Neurobiol. 2014 Mar;114:58-83.

15. Golpich M, Rahmani B, Mohamed Ibrahim N, Dargahi L, Mohamed Z, Raymond AA, Ahmadiani A. Preconditioning as a potential strategy for the prevention of Parkinson's disease. Mol Neurobiol. 2015 Feb;51(1):313-30.

16. Murry CE, Jennings RB, Reimer KA (1986) Preconditioning with ischemia: A delay of lethal cell injury in ischemic myocardium. Circulation 74(5):1124-1136.

17. Schott RJ, Schaper W. Ischemic preconditioning and myocardial stunning: related consequences of brief coronary occlusion and reperfusion? Adv Cardiol. 1990;37:32-41

18. Bolli R. Cardioprotective function of inducible nitric oxide synthase and role of nitric oxide in myocardial ischemia and preconditioning: an overview of a decade of research. J Mol Cell Cardiol. 2001 Nov;33(11):1897-918.

19. Hausenloy DJ, Candilio L, Laing C, Kunst G, Pepper J, Kolvekar S, Evans R, Robertson S, Knight R, Ariti C, Clayton T, Yellon DM;ERICCA Trial Investigators. Effect of remote ischemic preconditioning on clinical outcomes in patients undergoing coronary artery bypass graft surgery (ERICCA): rationale and study design of a multi-centre randomized double-blinded controlled clinical trial. Clin Res Cardiol (2012) 101:339-348.

20. Bousselmi R, Lebbi MA, and Ferjani M. Myocardial ischemic conditioning: Physiological aspects and clinical applications in cardiac surgery. J Saudi Heart Assoc. Apr 2014; 26(2): 93-100.

21. Eckle T, et al. (2012) Adora2b-elicited Per2 stabilization promotes a HIF-dependent metabolic switch crucial for myocardial adaptation to ischemia. Nat Med 18(5):774-782

22. Liu GS, Thornton J, Van Winkle DM, Stanley AWH, Olsson RA, and Downey JM. Protection against infarction afforded by preconditioning is mediated by $\mathrm{A} 1$ adenosine receptors in rabbit heart. Circulation 84: 350-356, 1991.

23. Philipp S, Yang X-M, Cui L, Davis AM, Downey JM, Cohen MV. Postconditioning protects rabbit hearts through a protein kinase $\mathrm{C}$-adenosine $\mathrm{A} 2 \mathrm{~b}$ receptor cascade.Cardiovasc Res. 2006;70:308-314.

24. Goto M, Liu Y, Yang X-M, Ardell JL, Cohen MV, and Downey JM. Role of bradykinin in protection of ischemic preconditioning in rabbit hearts. Circ Res 77: 611-621, 1995.

25. Saxena P, Aggarwal S, Misso NL, Passage J, Newman MA, Thompson PJ, d'Udekem Y, Praporski S, Konstantinov IE. Remote ischaemic preconditioning down-regulates kinin receptor expression in neutrophils of patients undergoing heart surgery. Interact Cardiovasc Thorac Surg. 2013 Oct;17(4):653-8.

26. Zager RA, Baltes LA, Sharma HM, Jurkowitz MS. Responses of the ischemic acute renal failure kidney to additional ischemic events. Kidney Int. 1984;26:689-700.

27. Mounsey RA, Pang CY, Forrest C. Preconditioning: a new technique for improved muscle flap survival. Otolaryngol Head Neck Surg.1992;107:549-552

28. Kitagawa K, Matsumoto M, Tagaya M, Hata R, Ueda H, Niinobe M, Handa N, Fukunaga R, Kimura K, Mikoshiba $\mathrm{K}$, Kamada T. 'Ischemic tolerance' phenomenon found in the brain. Brain Res. 1990;528:21-24.

29. Lloris-Carsi JM, Cejalvo D, Toledo-Pereyra LH, Calvo MA, Suzuki S. Preconditioning: effect upon lesion modulation in warm liver ischemia.Transplant Proc. 1993;25:3303-3304

30. Gho BC, Schoemaker RG, van den Doel MA, Duncker DJ, Verdouw PD (1996) Myocardial protection by brief ischemia in noncardiac tissue. Circulation 94(9):21932200 .

31. Dezfulian C1, Garrett M, Gonzalez NR Clinical application of preconditioning and postconditioning to achieve neuroprotection. Transl Stroke Res. 2013 Feb;4(1):19-24.

32. Hausenloy DJ, Yellon DM (2008) Remote ischaemic preconditioning: underlying mechanisms and clinical application. Cardiovasc Res 79:377-386.

33. Gill R, Kuriakose R, Gertz ZM, Salloum FN, Xi L, Kukreja $\mathrm{RC}$. Remote ischemic preconditioning for myocardial protection: update on mechanisms and clinical relevance. Mol Cell Biochem. 2015 Apr;402(1-2):41-9.

34. Pell TJ, Baxter GF, Yellon DM, Drew GM (1998) Renal ischemia preconditions myocardium: role of adenosine receptors and ATPsensitive potassium channels. Am J Physiol 275:H1542-H1547.

35. Tang ZL, Dai W, Li YJ, Deng HW (1999) Involvement of capsaicin- sensitive sensory nerves in early and delayed cardioprotection induced by a brief ischaemia of the small intestine. Naunyn Schmiedebergs Arch Pharmacol 359:243-247

36. Schoemaker RG, van Heijningen CL (2000) Bradykinin mediates cardiac preconditioning at a distance. Am J Physiol Heart Circ Physiol 278:H1571-H1576.

37. Patel HH, Moore J, Hsu AK, Gross GJ (2002) Cardioprotection at a distance: mesenteric artery occlusion protects the myocardium via an opioid sensitive mechanism. J Mol Cell Cardiol 34:1317-1323

38. Hajrasouliha AR, Tavakoli S, Ghasemi M, JabehdarMaralani P, Sadeghipour H, Ebrahimi F, Dehpour AR (2008) Endogenous cannabinoids contribute to remote ischemic preconditioning via cannabinoid $\mathrm{CB} 2$ receptors in the rat heart. Eur J Pharmacol 579:246-252

39. Addison PD, Neligan PC, Ashrafpour H, Khan A, Zhong A, Moses M, Forrest CR, Pang CYNoninvasive remote ischemic preconditioning for global protection of skeletal muscle against infarction. Am J Physiol Heart Circ Physiol. 2003 Oct;285(4):H1435-43.

40. Peart JN, Gross ER, Gross GJ. Opioid-induced preconditioning: recent advances and future perspectives. Vascul. Pharmacol. 2005;42:211-218.

41. Corti P, Gladwin MT (2014) Is nitrite the circulating endocrine effector of remote ischemic preconditioning? 
Circ Res 114:1554-1557.

42. Osswald H, Moerike K. Remote conditioning in clinical practice: a type of distant healing? Cardiology. 2011;119(4):214-6

43. Kristiansen SB, Nielsen-Kudsk JE, Bøtker HE, Nielsen TT. Effects of KATP channel modulation on myocardial glycogen content, lactate, and amino acids in nonischemic and ischemic rat hearts. J Cardiovasc Pharmacol. 2005 May;45(5):456-61.

44. Hausenloy DJ (2013) Cardioprotection techniques: preconditioning, postconditioning and remote conditioning (basic science). Curr Pharm Des 19:4544-4563.

45. Zhou B, Zhang PJ, Tian T, Jin C, Li Y, Feng M, Liu XY, Jie L, Tao LD. Role of vascular endothelial growth factor in protection of intrahepatic cholangiocytes mediated by hypoxic preconditioning after liver transplantation in rats. Transplant Proc. 2010 Sep;42(7):2457-62

46. Li J, Xuan W, Yan R, Tropak MB, Jean St Michel E, Liang W, Gladstone R, Backx PH, Kharbanda RK, Redington AN. Remote preconditioning provides potent cardioprotection via PI3K/AKT activation and is associated with nuclear accumulation of beta-catenin. Clin Sci (Lond). 2011; 120:451-462.

47. Diwan V, Kant R, Jaggi AS, Singh N, Singh D (2008) Signal mechanism activated by erythropoietin preconditioning and remote renal preconditioning-induced cardioprotection. Mol Cell Biochem 315:195-201.

48. Jones WK, Fan GC, Liao S, Zhang JM, Wang Y, Weintraub NL, Kranias EG, Schultz JE, Lorenz J, Ren X (2009) Peripheral nociception associated with surgical incision elicits remote nonischemic cardioprotection via neurogenic activation of protein kinase $\mathrm{C}$ signaling. Circulation 120:S1-S9

49. Kharbanda RK, Mortensen UM, White PA, Kristiansen SB, Schmidt MR, Hoschtitzky JA, et al.. Transient limb ischemia induces remote ischemic preconditioning in vivo. Circulation 2002;106(23):2881-3.

50. Loukogeorgakis SP, Panagiotidou AT, Broadhead MW, Donald A, Deanfield JE, MacAllister RJ. Remote ischemic preconditioning provides early and late protection against endothelial ischemia-reperfusion injury in humans: role of the autonomic nervous system. J Am Coll Cardiol. 2005 Aug 2;46(3):450-6.

51. Konstantinov IE, Arab S, Kharbanda RK, Li J, Cheung MM, Cherepanov V, Downey GP, Liu PP, Cukerman E, Coles JG, Redington AN. The remote ischemic preconditioning stimulus modifies inflammatory gene expression in humans. Physiol Genomics. 2004 Sep 16;19(1):143-50.

52. Park KM, Chen A, Bonventre JV. Prevention of kidney ischemia/reperfusion-induced functional injury and JNK, p38, and MAPK kinase activation by remote ischemic pretreatment. J Biol Chem. 2001 Apr 13;276(15):11870-6.

53. Heidbreder M, Naumann A, Tempel K, Dominiak P, Dendorfer A. Remote vs. ischaemic preconditioning: the differential role of mitogen-activated protein kinase pathways. Cardiovasc Res. 2008 Apr 1;78(1):108-15.

54. Hausenloy DJ, Lecour S, Yellon DM (2011) Reperfusion injury salvage kinase and survivor activating factor enhancement prosurvival signaling pathways in ischemic postconditioning: two sides of the same coin. Antioxid Redox Signal 14:893-907.

55. Thielmann M, et al. (2013) Cardioprotective and prognostic effects of remote ischaemic preconditioning in patients undergoing coronary artery bypass surgery: A single-centre randomised, double-blind, controlled trial. Lancet 382(9892):597-604.

56. Kalakech H, Tamareille S, Pons S, Godin-Ribuot D, Carmeliet P, Furber A, Martin V, Berdeaux A, Ghaleh B, Prunier F. Role of hypoxia inducible factor- $1 \alpha$ in remote limb ischemic preconditioning. J Mol Cell Cardiol. 2013 Dec;65:98-104

57. Cai Z, Luo W, Zhan H, Semenza GL.Hypoxia-inducible factor 1 is required for remote ischemic preconditioning of the heart. Proc Natl Acad Sci U S A. 2013 Oct 22;110(43):17462-7.

58. Albrecht M, Zitta K, Bein B, Wennemuth G, Broch O, Renner J, Schuett T, Lauer F, Maahs D, Hummitzsch L, Cremer J, Zacharowski K, Meybohm P (2013) Remote ischemic preconditioning regulates HIF-1alpha levels, apoptosis and inflammation in heart tissue of cardiosurgical patients: a pilot experimental study. Basic Res Cardiol 108:314

59. Ferdinandy P, Hausenloy DJ, Heusch G, Baxter GF, Schulz R. Interaction of risk factors, comorbidities, and comedications with ischemia/reperfusion injury and cardioprotection by preconditioning, postconditioning, and remote conditioning. Pharmacol Rev. 2014 Oct;66(4):1142-74.

60. Günaydin B, Cakici I, Soncul H, Kalaycioglu S, Cevik C, Sancak B, Kanzik I, Karadenizli Y. Does remote organ ischaemia trigger cardiac preconditioning during coronary artery surgery? Pharmacol Res. 2000 Apr;41(4):493-6.

61. Cheung M.M., Kharbanda R.K., Konstantinov I.E., Shimizu M., Frndova H., Li J. Randomized controlled trial of the effects of remote ischemic preconditioning on children undergoing cardiac surgery: first clinical application in humans. J Am Coll Cardiol. 2006;47(11):2277-2282

62. Jones BO, Pepe S, Sheeran FL, Donath S, Hardy P, Shekerdemian L, Penny DJ, McKenzie I, Horton S, Brizard CP, d'Udekem Y, Konstantinov IE,Cheung MM. Remote ischemic preconditioning in cyanosed neonates undergoing cardiopulmonary bypass: a randomized controlled trial. J Thorac Cardiovasc Surg. 2013 Dec;146(6):1334-40.

63. Takagi H., Umemoto T. Remote ischemic preconditioning for cardiovascular surgery: an updated meta-analysis of randomized trials. Vasc Endovascular Surg. 2011; 45(6):511-513.

64. Manchurov V, Ryazankina N, Khmara T, Skrypnik D, Reztsov R, Vasilieva E2, Shpektor A. Remote ischemic preconditioning and endothelial function in patients with acute myocardial infarction and primary PCI. Am J Med.2014 Feb 21

65. Slagsvold KH, Rognmo O, Høydal M, Wisløff U, Wahba A. Remote ischemic preconditioning preserves mito- 
chondrial function and influences myocardial microRNA expression in atrial myocardium during coronary bypass surgery. Circ Res. 2014 Feb 28;114(5):851-9.

66. Pavione MA, Carmona F, de Castro M, Carlotti AP. Late remote ischemic preconditioning in children undergoing cardiopulmonary bypass: a randomized controlled trial. J Thorac Cardiovasc Surg. 2012 Jul;144(1):178-83.

67. Wider J, Przyklenk K. Ischemic conditioning: the challenge of protecting the diabetic heart. Cardiovasc Diagn Ther. 2014 Oct;4(5):383-396.

68. Savaj S, Savoj J, Jebraili I, Sezavar SH. Remote Ischemic Preconditioning for Prevention of Contrast-induced Acute Kidney Injury in Diabetic Patients. Iran J Kidney Dis. 2014 Nov;8(6):457-60.

69. Camara-Lemarroy CR. Remote ischemic preconditioning as prevention of transfusion-related acute lung injury. Med Hypotheses. 2014 Sep;83(3):273-5.

70. Jean-St-Michel E, Manlhiot C, Li J, Tropak M, Michelsen MM, Schmidt MR, McCrindle BW, Wells GD, Redington AN. Remote preconditioning improves maximal performance in highly trained athletes. Med Sci Sports Exerc. $2011 \mathrm{Jul} ; 43(7): 1280-6$.

71. de Groot PC, Thijssen DH, Sanchez M, Ellenkamp R, Hopman MT. Ischemic preconditioning improves maximal performance in humans. Eur J Appl Physiol. 2010 Jan;108(1):141-6.

72. Bailey TG, Birk GK, Cable NT, Atkinson G, Green DJ, Jones H, Thijssen DH. Remote ischemic preconditioning prevents reduction in brachial artery flow-mediated dilation after strenuous exercise. Am J Physiol Heart Circ Physiol. 2012 Sep 1;303(5):H533-8.

73. Kjeld T, Rasmussen MR, Jattu T, Nielsen HB, Secher $\mathrm{NH}$. Ischemic preconditioning of one forearm enhances static and dynamic apnea. Med Sci Sports Exerc. 2014 Jan;46(1):151-5.

74. Barbosa TC, Machado AC, Braz ID, Fernandes IA, Vianna LC, Nobrega AC, Silva BM. Remote ischemic preconditioning delays fatigue development during handgrip exercise. Scand J Med Sci Sports. 2014 Apr 15 [Epub ahead of print].

75. Cheung M.M., Kharbanda R.K., Konstantinov I.E., Shimizu M., Frndova H., Li J. Randomized controlled trial of the effects of remote ischemic preconditioning on children undergoing cardiac surgery: first clinical application in humans. J Am Coll Cardiol. 2006;47(11):2277-2282.

76. Berger MM, Köhne H, Hotz L, Hammer M, Schommer $\mathrm{K}$, Bärtsch P, Mairbäurl H. Remote ischemic preconditioning delays the onset of acute mountain sickness in normobaric hypoxia. Physiol Rep. 2015 Mar;3(3). pii: e12325.

77. Lalonde F , Curnier DY. Can anaerobic performance be improved by remote ischemic preconditioning? J Strength Cond Res. 2015 Jan;29(1):80-5.

78. Twine CP, Ferguson S, Boyle JR. Benefits of remote ischaemic preconditioning in vascular surgery. Eur J Vasc Endovasc Surg. 2014 Aug;48(2):215-9.

79. Basovich SN. Trends in the use of preconditioning to hy- poxia for early prevention of future life diseases. Biosci Trends. 2013 Feb;7(1):23-32.

80. Prokopov AF. Intermittent Hypoxia and Health: From Evolutionary Aspects to Mitochondria Rejuvenation. In: Lei Xi \& Tatiana V. Serebrovskaya (Eds). Intermittent Hypoxia and Human Diseases / Springer, UK, 2012, Chapter 21, p. 253-269.

81. Xi L, Serebrovskaya TV (Eds). Intermittent Hypoxia: From Molecular Mechanisms to Clinical Applications. Nova Science Publishers NY. 2009; 602 pp.

82. Xi L, Serebrovskaya T (eds) (2012) Intermittent hypoxia and human diseases. Springer, London, $316 \mathrm{pp}$.

83. Serebrovskaya TV, Nosar VI, Bratus LV, Gavenauskas BL, Mankovska IM. Tissue oxygenation and mitochondrial respiration under different modes of intermittent hypoxia. High Alt Med Biol. 2013 Sep;14(3):280-8.

84. Navarrete-Opazo A, Mitchell GS. Therapeutic potential of intermittent hypoxia: a matter of dose. Am J Physiol Regul Integr Comp Physiol. 2014 Nov 15;307(10):R1181-97.

85. Rafibekova Zh, Dzhumangulova AS, Usubaliev NN, Abramovich EM. Treatment of hypertension disease by hypobaric barochamber hypoxia and middle altitudes. In: IX Congress of Therapeutists, abstract vol. 3, Tashkent, pp. 29-31, 1987.

86. Meerson F.Z., Tverdokhlib V.P., Soev V.M. (1989). [Adaptation to periodic hypoxia in therapy and prophylaxis]. Moscow: Nauka, 70 pp [Russian].

87. Ushakov IB, Cherniakov IN, Shishov AA, Olenev NI. [Hypobaric variant of interval hypoxic training in aerospace medicine]. Voen Med Zh. 2003 Feb;324(2):54-7.

88. Gao L, Chen L, Lu ZZ, Gao H, Wu L, Chen YX, Zhang CM, Jiang YK, Jing Q, Zhang YY, Yang HT. Activation of $\alpha 1 \mathrm{~B}$-adrenoceptors contributes to intermittent hypobaric hypoxia-improved postischemic myocardial performance via inhibiting MMP-2 activation. Am J Physiol Heart Circ Physiol. 2014 Jun 1;306(11):H1569-81.

89. Esteva S , Panisello P, Ramon Torrella J, Pages T, Viscor G. Enzyme activity and myoglobin concentration in rat myocardium and skeletal muscles after passive intermittentsimulated altitude exposure. J Sports Sci. 2009 Apr;27(6):633-40.

90. Li RC, Lee SK, Pouranfar F, Brittian KR, Clair HB, Row BW, Wang Y, Gozal D. Hypoxia differentially regulates the expression of neuroglobin and cytoglobin in rat brain. Brain Res. 2006 Jun 22;1096(1):173-9.

91. Mackenzie R, Watt P \& Castle P. Acute hypoxia and exercise improve insulin sensitivity SI2* in individuals with type 2 diabetes. Endocrine Abstracts (2009) 19 P162.1

92. Zhang JZ BA, Ismail-Beigi F. Regulation of glucose transport by hypoxia. Am J Kidney Dis. 1999 Jul;34(1):189-202.

93. Prabhakar NR FR, Baker T, Fletcher EC.Intermittent hypoxia: cell to system. Am J Physiol Lung Cell Mol Physiol. 2001 Sep;281(3):L524-8.

94. Nanduri J, Vaddi DR, Khan SA, Wang N, Makarenko V, Semenza GL, Prabhakar NR. HIF-1 $\alpha$ activation by intermittent hypoxia requires NADPH oxidase stimulation by xanthine oxidase. PLoS One. 2015 Mar 
9;10(3):e0119762.

95. Brugniaux JV, Pialoux V, Foster GE, Duggan CT, Eliasziw M, Hanly PJ, Poulin MJ. Effects of intermittent hypoxia on erythropoietin, soluble erythropoietin receptor and ventilation in humans. Eur Respir J , 2011 Apr;37(4):880-7

96. Dale EA, Mitchell GS. Spinal vascular endothelial growth factor (VEGF) and erythropoietin (EPO) induced phrenic motor facilitation after repetitive acute intermittent hypoxia. Respir Physiol Neurobiol. 2013 Feb 1;185(3):481-8.

97. Zhong N, Zhang Y, Zhu HF, Zhou ZN.. Intermittent hypoxia exposure prevents mtDNA deletion and mitochondrial structure damage produced by ischemia/reperfusion injury. Sheng Li Xue Bao. 2000 Oct;52(5):375-80.

98. Yeh CH, Hsu SP, Yang CC, Chien CT, Wang NP. Hypoxic preconditioning reinforces HIF-alpha-dependent HSP70 signaling to reduce ischemic renal failure-induced renal tubular apoptosis and autophagy. Life Sci. 2010 Jan 16;86(3-4):115-23.

99. Xinghe Wang JD, David W Boyle, Jin Zhong and WeiHua Lee. Potential Role of IGF-I in Hypoxia Tolerance Using a Rat Hypoxic-Ischemic Model: Activation of Hypoxia-Inducible Factor 1ó. Pediatric Research (2004) 55, 385-394.

100. Wang X, Deng J, Boyle DW, Zhong J, Lee WH. Potential role of IGF-I in hypoxia tolerance using a rat hypoxicischemic model: activation of hypoxia-inducible factor 1alpha. Eur Respir J. 2011 Apr;37(4):880-7.

101. Steshenko MM, Gonchar OO, Mankovska MI. Mitochondrial oxidative violations during hypoxia and its correction by means of interval hypoxic-hyperoxic training. Exper \& Clin Physiol and Biochem. 2010; (1): 12-17.

102. Mankovska IM, Serebrovskaya TV. Mitochondria as a target of intermittent hypoxia: a review . Fiziol.Zh, 2014, $60(6): 75-86$.

103. Manukhina EB, Pshennikova MG, Malyshev IYu, Mallet RT, and Downey HF. Protective Effects of Adaptation to Hypoxia in Experimental Alzheimer's Disease. In: Lei Xi \& Tatiana V. Serebrovskaya (Eds). Intermittent Hypoxia and Human Diseases / Springer, UK, 2012, Chapter 13, p. 155-171.

104. Serebrovskaya TV, Nikolsky IS, Nikolska VV, Mallet RT, Ishchuk VA . Intermittent hypoxia mobilizes hematopoietic progenitors and augments cellular and humoral elements of innate immunity in adult men. High Alt Med Biol. 2011;12(3):243-52.

105. Wang H, Yuan G, Prabhakar NR, Boswell M, Katz DM.Secretion of brain-derived neurotrophic factor from $\mathrm{PC} 12$ cells in response to oxidative stress requires autocrine dopamine signaling. J Neurochem. 2006 Feb;96(3):694-705.

106. Lukyanova L.D., Kirova Yu. I., and Germanova E.L. Energotropic Effects of Intermittent Hypoxia: Role of Succinate-Dependent Signaling. In: Lei Xi \& Tatiana V. Serebrovskaya [Eds]. Intermittent Hypoxia and Human Diseases. Springer, UK, 2012, Chapter 20, pp. 239-252.
107. Muscari C GE, Bonafe F, Govoni M, Pasini A, Guarnieri C. Priming adult stem cells by hypoxic pretreatments for applications in regenerative medicine. J Biomed Sci. 2013 Aug 29;20:63.

108. Rozova K.V., Mankovska I.N. [2012]. Effect of intermittent hypoxic training on lung and heart tissues of healthy rats. Pneumonologia i Alergologia Polska. 80[4]: 296-300.

109. Lane SW DAWD, and Watt FM. Modulating the stem cell niche for tissue regeneration. Nature Biotechnology, 2014, 32: 795-803.

110. Rennert RC SM, Garg RK, Gurtner GC. Stem cell recruitment after injury: lessons for regenerative medicine. Regen Med. 2012 Nov;7(6):833-50.

111. Wee J, Climstein M. Hypoxic training: Clinical benefits on cardiometabolic risk factors. J Sci Med Sport. 2015 Jan;18(1):56-61.

112. Serebrovska TV, Shatilo VB. Use of intermittent hypoxia for the prevention and treatment of cardiovascular diseases. Review. Circulation and hemostasis, 2014, \# 1-2, 16-33 [in Ukrainian].

113. Rachok LV, Dubovik TA, Bulgak AG, Ostrovsky YP, Kolyadko MG, Belskaya MI, Zhujko EN, Russkikh II. The effects of using normobaric intermittent hypoxia training as a method of preoperative preparation for coronary bypass surgery of the ischemic cardiomyopathie patients. Cardiology in Belarus. 2011; 17:28-45.

114. Nudelman LM. Interrupted normobaric hypoxytherapy in preoperational preparation of the patients. In: Normobaric hypoxytherapy in oncology (Strelkov RB, ed.). Bumazhnaya galereia Publishers, Moscow, Russia, 2003; pp. 61-69.

115. Pilyavskaya AN, Adiyatullin AI, Tkachouk EN. Interval hypoxic training in preparation to planned abdominal delivery. 2. Effect of the free radical-mediated oxidation parameters in blood plasma of pregnant women, in umbilical blood and in placenta. Hypoxia Medical Journal. 1997; 5:14-17.

116. Korkushko O.V., Shatilo V.B., Ishchuk V.A. Efficacy of intermittent normobaric hypoxic trainings in elderly patients with essential hypertension. Bulletin of Hygiene and Epidemiology. 2007; 11(1):14-17. [In Ukrainian]

117. Korkushko OV, Shatilo VB, Ishchuk VA, Tourta MI. .USE OF intermittent normobaric hypoxia trainings in elderly people. In: Xi L, Serebrovskaya TV (Eds). Intermittent hypoxia: from molecular mechanisms to clinical applications. Nova Science Publishers, Inc, New York, 2009; Chapter 28, p. 537-548.

118. Korkushko OV, Shatilo VB, Ishchuk VA. [Effectiveness of intermittent normabaric hypoxic trainings in elderly patients with coronary artery disease]. Adv Gerontol. 2010;23(3):476-82.

119. Lopata VA and Serebrovskaya TV. Hypoxicators: Review of the Operating Principles and Constructions. In: Lei Xi \& Tatiana V. Serebrovskaya (Eds). Intermittent Hypoxia and Human Diseases / Springer, UK, 2012, Chapter 24, 281-289. 
120. Tkachouk EN, Tsyganova TN, Staebler R. Apparatus for producing a hypoxic gaseous mixture using hollow fibers of poly-4-methilpenthene-1. US Patent 5,383,448, A62B 7/10, 24 Jan 1995.

121. Nemerovski LI. Construction principles of apparatus for intermittent normobaric hypoxia. Med Technika. 1992;1:3-8 [In Russian].

122. Arkhipenko YV, Sazontova TG, Zhukova AG. Adaptation to periodic hypoxia and hyperoxia improves resistance of membrane structures in heart, liver, and brain. Bull Exp Biol Med. 2005 Sep;140(3):278-81.

123. Glazachev OS, Zvenigorodskaia LA, Dudnik EN, Iartseva LA, Mishchenkova TV, Platonenko AV, Spirina GK. Interval hypoxic-hyperoxic training in the treatment of the metabolic syndrome. Eksp Klin Gastroenterol. 2010; 7:51-56.

124. Sazontova TG, Bolotova AV, Bedareva IV, Kostina NV, and Arkhipenko YuV. Adaptation to intermittent hypoxia/ hyperoxia enhances efficiency of exercise training. In: Lei Xi \& Tatiana V. Serebrovskaya (Eds). Intermittent Hypoxia and Human Diseases / Springer, UK, 2012, Chapter 16, p. 191-205.

125. Gonchar O, Mankovska I. Moderate hypoxia/hyperoxia attenuates acute hypoxia-induced oxidative damage and improves antioxidant defense in lung mitochondria. Acta Physiol Hung. 2012 Dec;99(4):436-46.

126. ArchipenkoYuA, Sazontova TG, Glazachev OS, Platonenko VI. Method of increasing the non-specific adaptive capacities of a person based on hypoxic-hyperoxic gas mixtures. The patent for the invention RU № 2289432, published 20.12.2006.

127. Kostin A.I., Glazachev O.S., Platonenko A.V., Spirina G.K. Device for carrying out complex interval normobarichypoxic-hyperoxic trainings of the person. Patent of the Russian Federation for the invention N2365384 from August, 27th, 2009 (the Application 2008104330).

128. Lemasters JJ, Bond JM, Chacon E et al (1996) The $\mathrm{pH}$ paradox in ischaemia-reperfusion injury to cardiac myocytes. EXS 76:99-114.

129. Sharma V, Cunniffe B, Verma AP, Cardinale M, Yellon D. Characterization of acute ischemia-related physiological responses associated with remote ischemic preconditioning: a randomized controlled, crossover human study. Physiol Rep. 2014 Nov 20;2(11).

130. Xia Z, Herijgers P, Nishida T, Ozaki S, Wouters P, Flameng W. Remote preconditioning lessens the deterioration of pulmonary function after repeated coronary artery occlusion and reperfusion in sheep. Can J Anaesth. 2003 May;50(5):481-8.

131. Kim JC, Shim JK, Lee S, Yoo YC, Yang SY, Kwak YL. Effect of combined remote ischemic preconditioning and postconditioning on pulmonary function in valvular heart surgery. Chest. 2012 Aug;142(2):467-75.

132. Levitzky M. The control of breathing. In: Levitzky MG, editor. Pulmonary physiology. 7th ed. New York: The McGraw-Hill Companies, Inc.; 2007, pp. 49-56.

133. Pokorski M. \& Serebrovskaya T. . Intermittent Hy- percapnia. In: Intermittent Hypoxia: From Molecular Mechanisms to Clinical Applications/. Editors: Lei Xi \& Tatiana V. Serebrovskaya/ Nova Science Publishers, 2009: 261-273.

134. Sharabi K., E. Lecuona, I.T. Helenius, G.J. Beitel, J.I. Sznajder, Y. Gruenbaum, Sensing, physiological effects and molecular response to elevated $\mathrm{CO} 2$ levels in eukaryotes. Journal of Cellular and Molecular Medicine 13 (2009) 4304-4318.

135. Eiam-ong S, Laski ME, Kurtzman NA, et al. Effect of respiratory acidosis and respiratory alkalosis on renal transport enzymes. Am J Physiol Renal Physiol. 1994; 267: F390-9.

136. Zippin JH, Farrell J, Huron D, et al. Bicarbonate-responsive "soluble" adenylyl cyclase defines a nuclear cAMP microdomain. J Cell Biol. 2004; 164: 527-34.

137. Jankov,R.P.;Lewis,P.;Kantores,C.;Ivanovska,J.;Xu,E.Z., VanVliet,T.;Lee,A. H.; Tanswell A.K., McNamara,P.J. Peroxynitrite mediates right-ventricular dysfunction in nitric oxide-exposed juvenile rats. Free Radic.Biol.Med. 2010, 49:1453-1467.

138. Vadasz I, Dada LA, Briva A, et al. AMPactivated protein kinase regulates $\mathrm{CO} 2$ - induced alveolar epithelial dysfunction in rats and human cells by promoting $\mathrm{Na}$,KATPase endocytosis. J Clin Invest. 2008; 118: 752-62.

139. Fu P, Sheng B, Li G. Enhancement of hypoxia tolerance and survival rate of Daphnia in severe hypoxia based on acidic preconditioning. Sheng Wu Yi Xue Gong Cheng Xue Za Zhi. 2012 Dec;29(6):1160-7.

140. Dunlop K, Gosal K, Kantores C, Ivanovska J, Dhaliwal R, Desjardins JF, Connelly KA, Jain A, McNamara PJ, Jankov RP. Therapeutic hypercapnia prevents inhaled nitric oxide-induced right-ventricular systolic dysfunction in juvenile rats. Free Radic Biol Med. 2014 Apr;69:35-49.

141. Belik J.; Stevens,D.;Pan,J.;Shehnaz,D.;Ibrahim,C.;Kantores,C.;Ivanovska, J. Grasemann,H.;Jankov,R.P.Chronic hypercapnia downregulates arginase expression and activity and increases pulmonary arterial smooth muscle relaxation in the newborn rat. Am. J.Physiol.LungCell. Mol.Physiol 297:L777-784; 2009.

142. Sewing AC, Kantores C, Ivanovska J, Lee AH, Masood A, Jain A, McNamara PJ, Tanswell AK, Jankov RP. Therapeutic hypercapnia prevents bleomycin-induced pulmonary hypertension in neonatal rats by limiting macrophage-derived tumor necrosis factor- $\alpha$. Am. J.Physiol. Lung.Cell.Mol.Physiol. 2012, 303:L75-87.

143. Wu X, Liu X, Zhu X, Tang C. Hypoxic preconditioning induces delayed cardioprotection through p38 MAPK-mediated calreticulin upregulation. Shock. 2007 May;27(5):572-7.

144. Zhang CH, Fan YY, Wang XF, Xiong JY, Tang YY, Gao JQ, Shen Z, Song XH, Zhang JY, Shen Y, Li Q, Zhang $\mathrm{X}$, Chen $\mathrm{Z}$. Acidic preconditioning protects against ischemia-induced brain injury. Neurosci Lett. 2012 Aug 8;523(1):3-8.

145. Ladilov Y. Preconditioning with hypercapnic acidosis: hope for the ischemic brain. Neurosci Lett. 2012 Aug 
8;523(1):1-2.

146. Zhang P, Shi X, Downey HF. Two-week normobaric intermittent-hypoxic exposures stabilize cerebral perfusion during hypocapnia and hypercapnia. Exp Biol Med (Maywood). 2014 Dec 11 [Epub ahead of print].

147. Fan JL, Kayser B. The effect of adding CO2 to hypoxic inspired gas on cerebral blood flow velocity and breathing during incremental exercise. PLoS One. 2013 Nov 21;8(11):e81130.

148. Snow JB, Kitzis V, Norton CE, Torres SN, Johnson KD, Kanagy NL, Walker BR, Resta TC. Differential effects of chronic hypoxia and intermittent hypocapnic and eucapnic hypoxia on pulmonary vasoreactivity. J Appl Physiol. 2008;104:110-118.

Received 10.10.2014 